Contributions:

A Study design/planning

B Data collection/entry

C Data analysis/statistics

D Data interpretation

D Data interpretation

E Preparation of manuscript
F Literature analysis/search

$G$ Funds collection

\section{ACADEMIC ACHIEVEMENT OF POLISH CHILDREN WITH COCHLEAR IMPLANTS AT THE END OF THEIR PRIMARY EDUCATION}

\author{
Malgorzata Zgoda ${ }^{1 A B D E F}$, Artur Lorens ${ }^{1 A C E}$, Anita Obrycka ${ }^{1 C D E}$, \\ Henryk Skarzynski ${ }^{2 A E}$
}
${ }^{1}$ Implants and Auditory Perception Department, Institute of Physiology and Pathology of Hearing, Warsaw/Kajetany, Poland
${ }^{2}$ Oto-Rhino-Laryngology Surgery Clinic, Institute of Physiology and Pathology of Hearing, Warsaw/Kajetany, Poland

Corresponding author: Malgorzata Zgoda, ul. Mokra 17, Kajetany, 05-830 Nadarzyn, +48 223560334, email address: m.zgoda@ifps.org.pl

\title{
Abstract
}

Background: Pediatric cochlear implant programs have been running in clinics around the world for more than 30 years. Application of a cochlear implant gives a deaf child the possibility of acquiring communication skills as good as those of their hearing peers. Reports of the school performance of deaf students who use cochlear implants are scarce. Reliable information is constrained by the difficulty of obtaining results from large groups of students with cochlear implants and of standardised tools to assess their academic abilities. The aim of this study was to evaluate the scores on a primary school competency test from children using cochlear implants and to compare them with scores from their typical hearing peers from Poland.

Materials and methods: The study group comprised 160 children with prelingual hearing loss. The measures for evaluating school achievements were the results of a standardised test at the end of primary school. Twenty one percent of the CI children did the standard version of the test (without any adjustments to the needs of students with a hearing loss), while the other $79 \%$ did an adjusted version of the test.

Results: In general, the mean scores achieved by the CI children who did the standard version of the school test were slightly better than the mean results of the typical hearing group sitting the same test. The differences of means in favor of CI children were 3.4 points in overall score (which had a maximum of 40 points), and $0.3,1.3,0.7,0.7$, and 0.6 respectively on the subscales of reading, writing, reasoning, using information, and practical application of knowledge. However, on an adjusted version of the test, the mean scores obtained by the CI children were somewhat lower than the mean scores for all the children doing the same test ( 2 points in overall score, and $1.1,0.5,0.4,0.02$, and 0.2 on each respective subscale).

Summary: The $21 \%$ of CI children who did the standard version of the school test (without any adjustments) had results which were on a par with those of children with normal hearing. The $79 \%$ who did the adjusted version of the test had results which were comparable to those of hard-of-hearing children.

Key words: deaf education • hearing loss • cochlear implant • school performance

\section{EVALUACIÓN DE LOS LOGROS ACADÉMICOS DE LOS NIÑOS CON IMPLANTES COCLEARES QUE TERMINAN LA ESCUELA PRIMARIA EN POLONIA}

\section{Resumen}

Introducción: Los programas de implante coclear pediátrico se han realizado en clínicas de todo el mundo durante más de treinta años. El uso de implantes cocleares en niños permite el desarrollo de una comunicación verbal que coincida con el nivel de los compañeros sin déficit auditivo. Sin embargo, la investigación científica en el área de los resultados escolares de los alumnos sordos que usan implantes cocleares es rara. Las dificultades aparecen por la dificultad de obtener resultados de grupos más grandes de estudiantes con implantes cocleares y el uso de herramientas estandarizadas para evaluar el rendimiento escolar.

El objetivo del estudio fue evaluar los resultados de las pruebas al final de la escuela primaria obtenidos por los niños que usan implantes cocleares y compararlos con los resultados de los pares polacos sin déficit.

Material y Método: El grupo de investigación consistió en 160 niños con pérdida auditiva prehabla. La medida adoptada en el estudio de evaluación del rendimiento escolar fue el resultado de una prueba estándar al final de la escuela primaria

Resultados: Los resultados promedio obtenidos por los niños del grupo de investigación que se unieron a la prueba estándar fueron ligeramente mejores que los resultados promedio de las personas sin déficit auditivo que pasaron la misma versión de la prueba. La diferencia media de puntos a favor de los niños con IC fue de 3.4 puntos en el resultado general (el número máximo de puntos era 40), seguido de 0.3 , 1.3 , 0.7, $0.7,0.6$ en las subcategorías de lectura, escritura, razonamiento, comprensión y uso del conocimiento en la práctica. Por el contrario, los resultados promedio obtenidos por los niños del grupo de estudio que escribieron la prueba en la versión adaptada a la discapacidad auditiva fueron ligeramente peores que los resultados promedio para la población de niños que también pasaron la prueba en una versión adaptada (-2 puntos en la puntuación general y $-1.1,-0.5,-0.4,-0.02,-0.2$ puntos en subcategorías individuales).

Resumen de resultados: El veinte por ciento de los niños del grupo de estudiantes que usaban implantes cocleares tomaron la versión estándar de la prueba (sin ajustar a la discapacidad auditiva) y obtuvieron resultados al nivel de la audición de sus compañeros. Los restantes niños examinados escribieron la prueba en la versión adaptada, y sus resultados fueron comparables a los resultados de los niños con discapacidad auditiva.

Palabras clave: educación de estudiantes con pérdida auditiva y sordera • pérdida auditiva • implante coclear • logros escolares 


\title{
ОЦЕНКА УСПЕВАЕМОСТИ ДЕТЕЙ С КОХЛЕАРНЫМИ ИМПЛАНТАМИ, ЗАКАНЧИВАЮЩИХ НАЧАЛЬНУЮ ШКОЛУ В ПОЛЬШЕ
}

\begin{abstract}
Аннотация
Более 30 лет в клиниках по всему миру проводятся детские программы по кохлеарной имплантации. Использование кохлеарных имплантов у детей позволяет развивать коммуникативные навыки и применять вербальные средства общения, соответствующие уровню слышащих сверстников. Тем не менее, в настоящее время было проведено очень мало научных исследований в области успеваемости глухих учеников, использующих кохлеарные импланты. Сложность состоит в получении результатов исследований более многочисленных групп учеников с кохлеарными имплантами, а также в применении стандартизированных методов оценки их успеваемости в школе.
\end{abstract}

Целью исследования является оценка результатов итоговых тестов учеников начальной школы, использующих кохлеарные импланты, а также сравнение данных тестов с результатами тестов польских сверстников.

Материалы и методы: Исследуемая группа состояла из 160 детей с прелингвальной потерей слуха. Критерием оценки успеваемости учащихся в проведенном исследовании явились результаты тестирования - стандартизированного метода оценки знаний, умений и навыков учащихся, оканчивающих начальную школу.

Результаты: Средние результаты, полученные в рамках исследования данной группы учащихся, которые прошли стандартное тестирование, были немногим лучше, чем средние результаты слышащих ровесников, которые писали идентичную версию теста. Разница между средними результатами в пользу детей с КИ составила 3,4 балла (максимальное количество баллов - 40) по общему результату, а в подкатегориях: чтение, письмо, рассуждение, использование информации, использование знаний на практике - 0.3, 1.3, 0.7, 0.7, 0.6 соответственно. И наоборот, средние результаты, полученные в рамках исследования группы учащихся, которые прошли тестирование в версии, адаптированной к слуховой инвалидности, были несколько хуже, чем средние результаты для всей популяции детей, которые также писали тест в адаптированной версии (на 2 балла в общем результате и $1.1,0.5,0.4,0.02,0.2$ балла в отдельных подкатегориях).

Выводы: Двадцать процентов детей из группы учеников, использующих кохлеарные импланты, прошли стандартную версию теста (без учета нарушения слуха) и получили результаты на уровне своих слышащих сверстников. Остальные обследованные дети писали тест в адаптированном варианте, в итоге их результаты были сопоставимы с результатами детей с нарушениями слуха.

Ключевые слова: обучение учеников с тугоухостью и глухотой • потеря слуха • кохлеарный имплант • успеваемость

\section{OCENA POZIOMU OSIĄGNIĘĆ SZKOLNYCH DZIECI KOŃCZĄCYCH NAUKE W SZKOLE PODSTAWOWEJ W POLSCE}

\section{Streszczenie}

Wprowadzenie: Pediatryczne programy implantów ślimakowych są prowadzone w klinikach na świecie od ponad trzydziestu lat. Zaś stosowanie implantów ślimakowych u dzieci pozwala na rozwój komunikacji werbalnej dorównującej poziomowi słyszących rówieśników. Jednak badania naukowe w obszarze wyników szkolnych uczniów głuchych korzystających z implantów ślimakowych są rzadkością. Trudności wynikają z możliwości uzyskania wyników większych grup uczniów z implantami ślimakowymi oraz wykorzystania standaryzowanych narzędzi do oceny osiągnięć szkolnych.

Celem pracy była ocena wyników sprawdzianu na zakończenie szkoły podstawowej uzyskanych przez dzieci używające implantów ślimakowych i porównanie ich z wynikami polskich rówieśników.

Materiał i Metoda: Grupa badawcza składała się z 160 dzieci z niedosłuchem prelingwalnym. Miarą przyjętą w badaniu do oceny osiągnięć szkolnych był wynik standaryzowanego sprawdzianu przeprowadzanego na zakończenie szkoły podstawowej

Wyniki: Średnie wyniki uzyskane przez dzieci z grupy badawczej, które przystapiły do sprawdzianu w wersji standardowej były nieco lepsze niż średnie wyniki rówieśników słyszących piszących tę samą wersję testu. Różnice średnich na korzyść dzieci z CI wynosiły 3,4 punktu (maksymalna liczba punktów wynosiła 40) w wyniku ogólnym, a kolejno: 0,3,1,3,0,7, 0,7, 0,6 w podkategoriach: czytanie, pisanie, rozumowanie, korzystanie z informacji, wykorzystywanie wiedzy w praktyce. I odwrotnie, średnie wyniki uzyskane przez dzieci z grupy badanej, które pisały test $\mathrm{w}$ wersji dostosowanej do niepełnosprawności słuchowej były nieco gorsze niż średnie wyniki dla całej populacji dzieci, które także pisały test w wersji dostosowanej (o 2 punkty w wyniku ogólnym oraz o: 1.1, 0.5, 0.4, 0.02, 0.2 punktu w poszczególnych podkategoriach).

Podsumowanie: Dwadzieścia procent dzieci z grupy badanej uczniów korzystających z implantów ślimakowych przystapiło do sprawdzianu w wersji standardowej (bez dostosowania do niepełnosprawności słuchowej) i osiągnęło wyniki na poziomie słyszących rówieśników. Pozostałe badane dzieci pisały test w wersji dostosowanej, a ich wyniki były porównywalne do wyników dzieci słabosłyszących.

Słowa kluczowe: edukacja uczniów z niedosłuchem i głuchotą • ubytek słuchu • implant ślimakowy • osiągnięcia szkolne

\section{Background}

Hearing loss present from birth hampers a child's speech and language development, affecting their access to education and in adult life limiting their choice of profession and chances of finding employment (1-5). There are many publications on the educational outcomes of deaf students, and in most cases they score at a lower level than students without any auditory disability (6-10).

Pediatric cochlear implant programs have been running in clinics around the world for more than 30 years (11). Application of a cochlear implant gives a deaf child the chance to perceive environmental and speech sounds, 
giving them the option to acquire hearing and communication skills equal to their hearing peers (12-14). There are, however, various factors - individual, medical, physiological, and psychological - affecting the final outcome, which can vary even among CI students with the same device (15). Reports presenting results of deaf school students who use cochlear implants are scarce. Reliable findings are limited by the difficulty of obtaining results from large groups of pupils with cochlear implants, and of the availability of standardised tools to assess their academic ability. Significantly, poor school performance at primary level may adversely affect a child's performance at higher stages of education right up to university level (16-18).

The pediatric cochlear implant program at the Institute of Physiology and Pathology of Hearing was started in 1992 (19). This long-standing cochlear implant program permits data to be collected for evaluating not only the short-term effects of implantation, but also the long-term functional outcomes, including the academic performance of implantees. The aim of this study was to evaluate the scores of a primary school competency test obtained by students using cochlear implants and to compare them to the scores of their Polish hearing peers.

\section{Material and methods}

The assessment of school achievements in this study was based on the results of a competency test performed at the end of primary school (20). The test, done by all students in the sixth grade of primary school, is the first obligatory external exam taken by children in the Polish education system. It began in 2002 but finished with the reform of the Polish education system in 2016. It was conducted in all schools in Poland on the same day and starting at the same hour. Its primary aim was to benchmark the children's abilities relative to a national standard. The test was universal and obligatory; all children had to sit the test in order to finish primary school. However, the test did not have any selective role; it served only as a source of information on the level of a student's achievements at the end of primary school.

In the case of students with special educational needs who took the exam (in particular, students with a hearing impairment), an Ordinance of the Minister of Education specified how to adjust the conditions and the form of the examination (21). Deaf and hard-of-hearing students who had a certificate of special education could sit the exam in the presence of a specialist (a teacher of the deaf or interpreter). They received a set of questions tailored to their impairment and received extra time to write the exam. The standard exam was 60 minutes; students with a disability who took the adjusted version of the test had an additional 30 minutes.

All students - those writing the standard exam and those writing the impairment-adjusted version - could obtain a maximum of 40 points. Each student later received a certificate showing their results from the Central Commission of Examination.

The range of competencies tested at the exam, in line with the standard specified by the Minister of National
Education, included five categories: reading, writing, reasoning, using information, and practical application of knowledge. Skills were not tested exclusively with text, but also with graphs, maps, etc., and tasks were designed to check skills from different subject areas.

This study was done using a specially designed questionnaire and was sent to participants by post. The study also made use of the patients' medical histories. The study was approved by the Bioethics Committee of the Institute of Physiology and Pathology of Hearing (decision number IFPS:/KB/04/2013).

The questionnaire comprised two parts, core and demographics. The core section contained questions about the results of the child's competency test at the end of primary school. Parents completed it based on data on the certificate provided by the Central Commission of Examination. The demographic part included a question on the year the child finished primary school; other questions focused on additional health and developmental problems, and on the cause of the child's hearing loss. Questionnaires, along with a return envelope, were sent to 478 parents of children with prelingual hearing loss who had been implanted at the Institute of Physiology and Pathology of Hearing. Children selected to participate in the study were cochlear implant users born between 1997 and 2000. At the time of the study, the youngest was 13 years old and so they should have just ended primary school. Children with multiple disabilities, as defined by the Education System Act (22), were excluded. Information about the study was included with the questionnaire as well as an informed consent form for the parents to sign. Parents returned 201 questionnaires, a return rate of $44 \%$. Forty-one questionnaires were excluded from the analysis due to lack of essential information or because the child had not yet finished primary school and hadn't taken the exam. In total, there were 160 children who were included in the study. The age of children at the time of the exam was between 11.4 and 15.9 years, and the age of $50 \%$ of the study group was $12.8-13.5$ years. The gender distribution was nearly equal, with $52.5 \%$ girls and $47.5 \%$ boys. Age at the time of implantation was between 1.5 and 13.4 years.

In order to compare the data of children with CIs with those from all Polish children, we obtained the raw results of the primary school competency test for all Polish pupils sitting the test in the years 2010-14. We obtained both versions: the standard one and the one adjusted for hard-of-hearing and deaf students. The school test results were analysed in terms of descriptive statistics, including the distribution of overall scores and the means and standard deviations of the overall score as well as for each subscale. The mean scores achieved by CI children were compared to the mean scores obtained by the total population of children sitting the test in Poland. In the present education system (which differs from that prior to 2017), the test at the end of primary school involves children two years older than in the study group. Because of this, a similar study repeated in the future would produce different results than those presented here. 


\section{Results}

Distributions of the overall scores obtained by the CI students in the primary school competency test are shown in Figure 1 for both the standard version (left) and adjusted version (right). For the standard version, the distribution of results is negatively skewed: $85 \%$ of the children achieved an overall score of more than 20 points, and $64 \%$ exceeded the mean of 24.5 points. For the adjusted version, the distribution is wider and flatter, indicating a higher range of outcomes than with the standard version of the test.

The mean scores achieved by the CI children who did the standard version of the test were in general slightly better than those of the typical hearing group who sat this version of the test. The differences in means in favor of the CI children were 3.4 points in terms of overall score, and $0.3,1.3,0.7,0.7$, and 0.6 respectively in reading, writing, reasoning, using information, and practical application of knowledge subscales. On the other hand, the mean scores obtained by children from the study group who used the adjusted version of the test were somewhat lower than the mean scores for the whole population of children doing the adjusted version ( 2 points lower in the overall score, and $1.1,0.5,0.4,0.02$, and 0.2 lower in each of the subscales).

Figure 2a compares the means and standard deviations of the overall scores obtained by children from the study group with those from the entire population. The specific scores associated with the particular skills of reading, writing, reasoning, using information, and practical application of knowledge are presented in Figures $2 b-2 e$.

\section{Discussion}

In the Polish education system, a student using a cochlear implant has the status of an impaired student, so they are entitled to take the primary school competency test in the form which is adjusted to the needs of hearing impaired students. In the study group, $21 \%$ of the CI children had done the test under the same conditions as children with no additional needs, while $79 \%$ did the adjusted version. Among the CI children sitting the standard test, $90 \%$ scored over 18 points (out of a maximum score of 40 ). In the stanine scale of the standard version used by

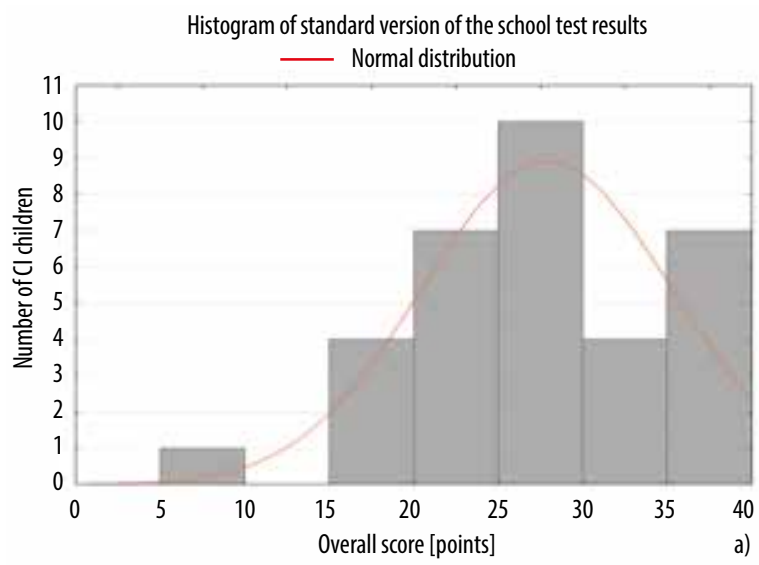

the Central Commission of Examination, our CI study group was placed in the range from the lower intermediate to high. Such a position reflects the high level of achievement of the group of CI children taking the standard version of the test (Figure 1a).

Studies which use in their methodology a standardised test of school achievements, such as used in the present study, report largely similar results. Results of this study are congruous with those reported by three other research groups (23-25). Spencer et al. have shown that the average school results of children with cochlear implants are comparable to or higher than those obtained by their hearing peers (23). Similar results were reported by Wu et al. who analysed the school achievements of a group of 35 children with cochlear implants, implanted at a young age, who attended mainstream schools (24). Zgoda et al. analysed school achievements of children implanted before the age of 3 years and found that these children obtained scores on the primary school competency test corresponding to at least the $5^{\text {th }}$ stanine of children without dysfunctions (25).

O’Neil et al. (2014) and Motasaddi-Zarandy et al. (2009) found that the achievements of CI children were no worse than those of children without special needs $(28,29)$.

On the other hand, Sarand et al. (2014) and Thoutenhoofd (2006) found school achievements of CI children to be below the level of children without special needs $(9,26)$. Sarand et al. (2014) reported that the percentage of CI children whose school achievement test score was below one standard deviation from the mean of children without dysfunction was much higher than expected for dysfunctionally free children (26). Thoutenhoofd (2006) reported that the school achievements of children using cochlear implants was lower than the national average score of hearing children (9).

The conclusion by Sarand et al. (2014) about lower scores for children with cochlear implants may have arisen from a different method of analysing the results. The Australians compared the percentage of children obtaining school results lower than one standard deviation, but in the present study the comparisons were based on mean scores. The difference between the results of the present study and

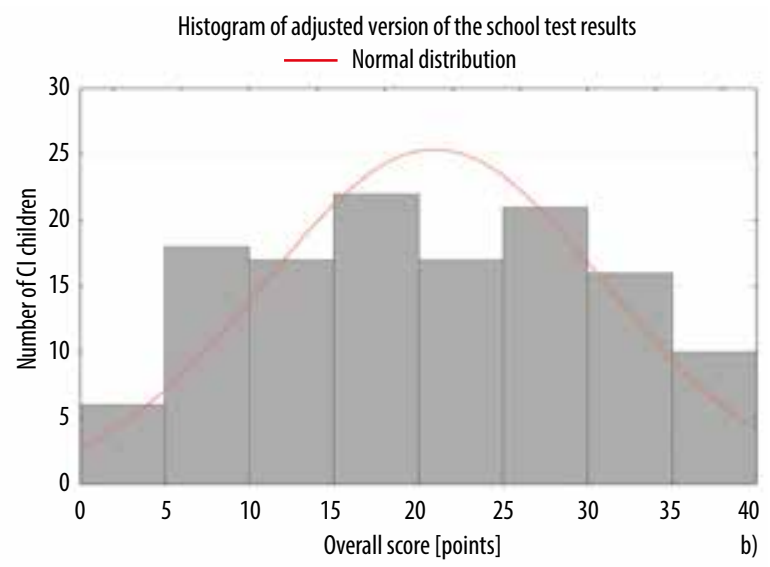

Figure 1. Distributions of overall scores of the school competency test in $\mathrm{Cl}$ children taking the standard version of the test (a) and the adjusted version (b) 
those of Thoutenhoofd (2006) may be due to the different ages of the children at the time of cochlear implantation in Thoutenhoofd's study the mean age at implantation was 7.07 years, while in the present study it is significantly lower (4.5 years). Early cochlear implantation enables a child with hearing impairment to develop auditory perception, speech, and language similar to those of a hearing child (12-14). It follows that early implanted children will have better rehabilitation than children provided with cochlear implants at an older age, and so it is expected that they will perform better at school (27). Thus, the higher level of achievements of the CI children reported in this study may be attributable to the younger age at implantation.
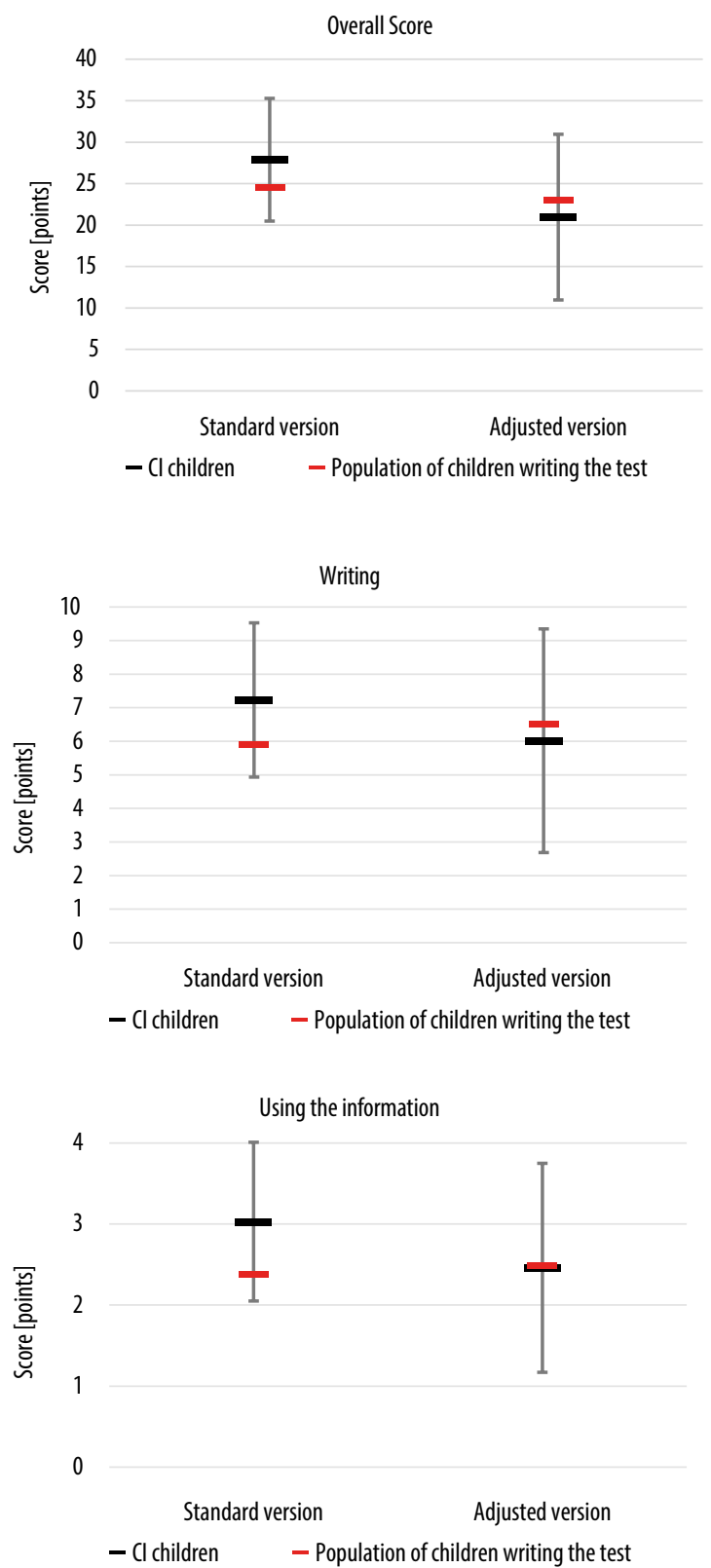

The results of the present study are also compatible with the results of two studies which used non-standardised tools for assessing school achievement. O'Neil et al. (2014) compared the average results of typical hearing students and students with a hearing loss based on the grades obtained by students in internal evaluations at the end of each school year (28). The mean in the group of CI users was the highest of all the groups of children with different degrees of hearing loss and in fact similar to the results of typical hearing children (28). Motasaddi-Zarandy et al. (2009), using a similar method to assess school achievements, concluded that the majority of CI users achieved school results higher than the mean of their typical hearing peers (29).
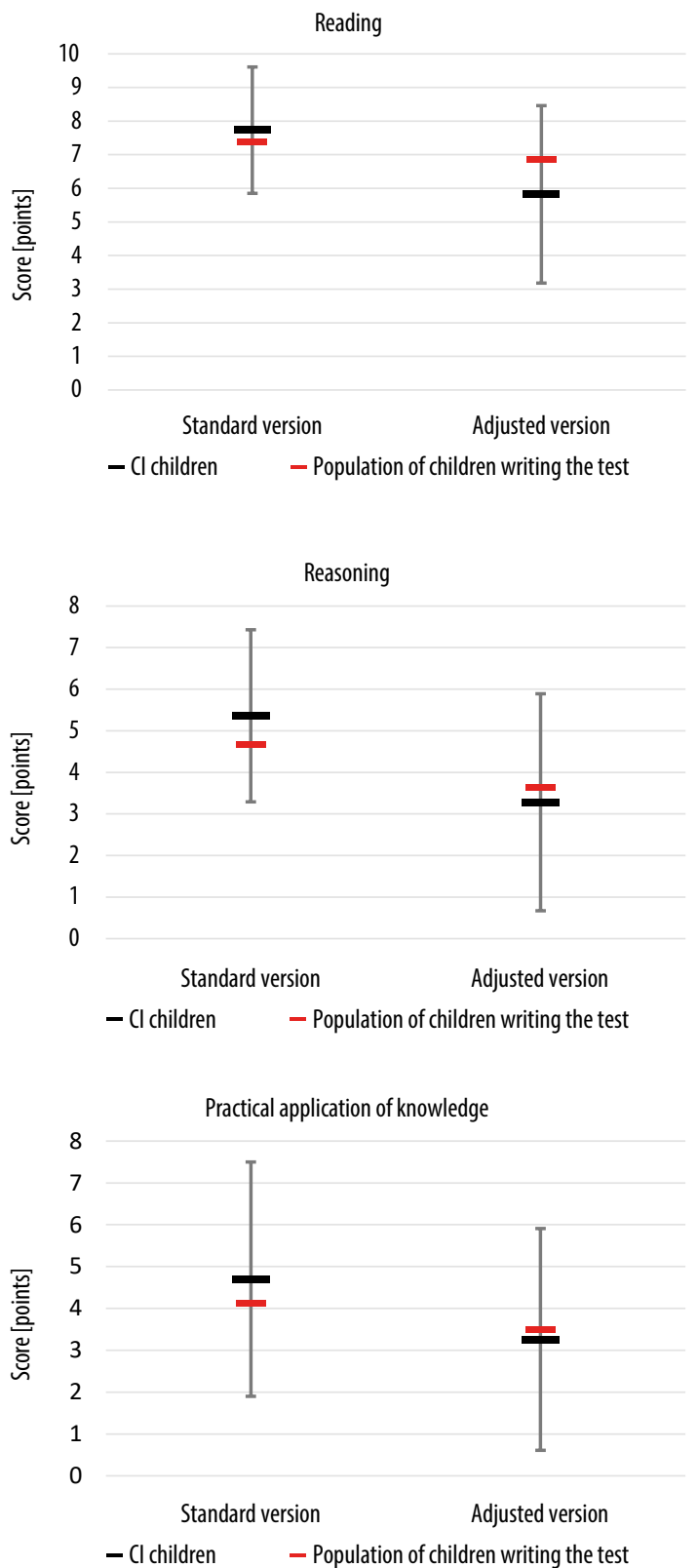

Figure 2. School competency test results (overall score and five subscales) for the standard version (left) and adjusted version (right). Black markers with error bars show means and standard deviations for $\mathrm{Cl}$ children; red markers show means for all children writing the test in Poland 
The results obtained by our CI children who did the adjusted version are characterised by a larger range and flatter distribution (Figure 1b). The results obtained by the children doing the adjusted test cannot be compared directly to the results of typical hearing children because of the different standards and conditions of taking the test in each group. However, comparisons may be made between children doing the adjusted version of the test, i.e. to children with less severe degrees of hearing loss. Data obtained from the Education Information System (SIO) shows that in the population of children with a hearing loss who did the adjusted version of the test, the majority were children defined in the functional classification as 'hard-of-hearing' (30-32).

We may therefore assume that comparison can be made between CI children and children with moderate hearing loss using hearing aids. The mean score on the primary school competency test for CI children was similar to the mean score of typical children. School achievements of CI children measured with standardised tools are similar to children with moderate hearing loss who use hearing aids. These results align with the results of Thoutenhoofd (2006) who, using a common nationwide tool to assess school competencies (the test range involved reading, writing, and math), found no statistically relevant differences in educational achievements between CI students and those with a moderate hearing loss (9). It should be noted that, according to two reports, students with moderate hearing loss obtain school competency levels closer to the results of typical hearing students than to students with a profound or even mild hearing loss who do not use any hearing device (33-34).

\section{Summary}

The $21 \%$ of CI children who did the standard version of the school test (without any adjustments to the needs of students with a hearing loss) had results which were on a par with those of children with normal hearing. The other $79 \%$ of children who did the adjusted version of the test had results which were comparable to those of hardof-hearing children.

\section{Acknowledgments}

The work was supported by the Polish National Science Centre, decision no. DEC-2013/09/N/NZ7/03586.

The study was approved by the bioethics committee of the Institute of Physiology and Pathology of Hearing, number IFPS:/KB/04/2013

\section{References}

1. Karchmer M, Allen T. The functional assessment of deaf and hard of hearing students. Am Ann Deaf, 1999; 144: 68-77.

2. Venail F, Vieu A, Artieres F, Mondain M, Uziel A. Educational and employment achievements in prelingually deaf children who receive cochlear implants. Arch Otolaryngol Head Neck Surg, 2010; 136: 366-72.

3. Schroeder L, Petrou S, Kennedy C, et al. The economic costs of congenital bilateral permanent childhood hearing impairment. Pediatrics, 2006; 117(4), 1101-12.

4. Schley S, Walter G, Weathers R, Hemmeter J, Hennessey J, Burkhauser R. Effect of postsecondary education on the economic status of persons who are deaf or hard of hearing. J Deaf Stud Deaf Edu, 2011; 16(4), 524-36.

5. Van Gent T, Sleeboom-van Raaij I. Mental health problems in deaf and severely hard-of-hearing children and adolescents: an overview. In: Marschark M, Lampropoulou V, Skordilis E, eds. Diversity in Deaf Education. New York: Oxford University Press, 2016. pp. 381-416.

6. Hendar O, O'Neill R. Monitoring the achievement of deaf pupils in Sweden and Scotland: approaches and outcome. Deafness and Education International, 2016; 18, 47-56.

7. Lederberg A, Schick B, Spencer P. Language and literacy development of deaf and hard-of-hearing children: successes and challenges. Develop Psychol, 2013; 49, 15-30.

8. Punch R, Hyde M. Communication, psychosocial, and educational outcomes of children with cochlear implants and challenges remaining for professionals and parents. Int J Otolaryngol, 2011; Article ID 573280.

9. Thoutenhoofd E. Cochlear implanted pupils in Scottish schools: 4-year school attainment data (2000-2004). J Deaf Stud Deaf Edu, 2006; 11(2), 171-88.

10. Traxler C. The Stanford Achievement Test, 9th Edition: National norming and performance standards for deaf and hard-of-hearing students. J Deaf Stud Deaf Edu, 2000; 5, 337-48.
11. Berliner K, Luxford W, House W, Tonokawa L. Cochlear implants in children. In: Myers E, Bluestone C, Brackmann D, Krause C, eds: Advances in Otolaryngology Head and Neck Surgery, Vol 4. St Louis, MO. Mosby Year Book, 1990, pp 61-79.

12. Obrycka A, Lorens A, Piotrowska A, Skarżyński H. Ocena rozwoju słuchowego dzieci z głębokim niedosłuchem, którym wszczepiono implant ślimakowy we wczesnym dzieciństwie, Now Audiofonol, 2014; 3(5): 59-65.

13. Tajudeen B, Waltzman S, Jethanamest D, Svirsky M. Speech perception in congenitally deaf children receiving cochlear implants in the first year of life. Otol Neurotol, 2010; 31: 1254-60.

14. De Raeve L. A longitudinal study on auditory perception and speech intelligibility in deaf children implanted younger than 18 months in comparison to those implanted at later ages. Otol Neurotol, 2010; 31(8), 1261-7.

15. Olusanya B, Neumann K, Saunders J. The global burden of disabling hearing impairment: a call to action. Bull World Health Organization, 2014; 92(5), 367-73.

16. Nagle K, Newman L, Shaver D, Marschark M. College and career readiness: course taking of deaf and hard of hearing secondary school students. Am Ann Deaf, 2016; 160, 467-82.

17. Rydberg E, Gellerstedt L, Danermark B. Toward an equal level of educational attainment between deaf and hearing people in Sweden? J Deaf Stud Deaf Edu, 2009; 14, 312-23.

18. Winn S. Employment outcomes for people in Australia who are congenitally deaf: has anything changed? Am Ann Deaf, 2007; $152,382-90$.

19. Skarżyński H, Janczewski G, Geremek A, Niemczyk K, Klasek O, Kochanek K. Pierwszy wszczep ślimakowy w Polsce. Otolaryngol Pol, 1993; 47(5): 427.

20. Rozporządzenie Ministra Edukacji Narodowej z dnia 30 kwietnia 2007 r. w sprawie warunków i sposobu oceniania, klasyfikowania i promowania uczniów i słuchaczy oraz przeprowadzania sprawdzianów i egzaminów w szkołach publicznych. 
21. Rozporządzenie Ministra Edukacji Narodowej z dnia 17 listopada 2010 r. w sprawie warunków organizowania kształcenia, wychowania i opieki dla dzieci i młodzieży niepełnosprawnych oraz niedostosowanych społecznie w przedszkolach, szkołach i oddziałach ogólnodostępnych lub integracyjnych.

22. Ustawa $\mathrm{z} 7$ września 1991 o systemie oświaty.

23. Spencer L, Gantz B, Knutson J. Outcomes and achievement of students who grew up with access to cochlear implants. Laryngoscope, 2004; 114(9), 1576-81.

24. Wu C, Liu T, Liao P, Chen C, Chang B, Lin B. Academic achievements and classroom performance in Mandarin-speaking prelingually deafened school children with cochlear implants. Int J Pediatr Otorhinolaryngol, 2013; 77(9), 1474-80.

25. Zgoda M, Obrycka A, Putkiewicz-Aleksandrowicz J, Lorens A, Skarżyński H. Analiza porównawcza osiągnięć szkolnych trzynastolatków korzystających z implantu ślimakowego wszczepionego im przed ukończeniem 3 roku życia i słyszących rówieśników. Now Audiofonol, 2014; 3(5), 66-74.

26. Sarant J, Harris D, Bennet L. Academic outcomes for school-aged children with severe-profound hearing loss and early unilateral and bilateral cochlear implants. J Speech Lang Hear Res, 2015; 58, 1017-32.

27. Tobey E, Thal D, Niparko J, Eisenberg L, Quittner A, Wang N. Influence of implantation age on school-age language performance in pediatric cochlear implant users, Int J Audiol, 2013; 52(4): 219-29.
28. O'Neill R, Arendt J, Marschark M. Report from the Achievement and Opportunities for Deaf Students in the United Kingdom: from Research to Practice project, 2014; Available from: http://www. nuffieldfoundation.org/sites/default/files/files/EDU\%2037468\%20 -\%20Nuffield\%20Report\%20MASTER\%20v3.pdf

29. Motasaddi-Zarandy M, Rezai H, Mahdavi-Arab M, Golestan B. The scholastic achievement of profoundly deaf children with cochlear implants compared to their normal peers. Arch Iran Med, 2009; 12(5), 441-7.

30. Uczniowie ze specjalnymi potrzebami edukacyjnymi wg typów szkół: wg stanu na 30 września 2011. System Informacji Oświatowej. Available from: http://www.cie.men.gov.pl/index. $\mathrm{php} /$ dane-statystyczne/139.html

31. Uczniowie ze specjalnymi potrzebami edukacyjnymi wg typów szkół: wg stanu na 30 września 2012. System Informacji Oświatowej. Available from: http://www.cie.men.gov.pl/index. $\mathrm{php} /$ dane-statystyczne/139.html

32. Uczniowie ze specjalnymi potrzebami edukacyjnymi wg województw w roku szkolnym 2013/2014: wg stanu na 30.09.2013 r. System Informacji Oświatowej. Available from: http://www.cie. men.gov.pl/index.php/dane-statystyczne/139.html

33. Sarant J, Hughes K, Blamey P. The effect of IQ on spoken language and speech perception development in children with impaired hearing. Cochlear Implants Int, 2010; 11 (Suppl 1), 370-74.

34. Marschark M, Shaver D, Nagle K, Newman L. Predicting the academic achievement of deaf and hard-of-hearing students from individual, household, communication, and educational factors. Except Child, 2015; 81(3), 350-69. 